\title{
Independent Directors, Female Directors and Performance of Financial Listed Companies in China
}

\author{
Chuanyi Zeng \\ Department of Finance, College of Economics, Jinan University, Guangzhou, China \\ Email: zcyajbr@126.com
}

How to cite this paper: Zeng, C.Y. (2018) Independent Directors, Female Directors and Performance of Financial Listed Companies in China. Modern Economy, 9, 652-663. https://doi.org/10.4236/me.2018.94042

Received: March 12, 2018

Accepted: April 21, 2018

Published: April 24, 2018

Copyright $\odot 2018$ by author and Scientific Research Publishing Inc. This work is licensed under the Creative Commons Attribution International License (CC BY 4.0).

http://creativecommons.org/licenses/by/4.0/

\begin{abstract}
Both independent and female directors are important parts of the board composition. This paper empirically examines the impact of independent directors' background and the size of independent directors and female directors. The background of independent directors has positive effect on the performance of Chinese financial listed companies. The size of independent directors, female directors and female independent directors has no significant effect on corporate performance. This result provides an empirical evidence for the reform of corporate governance in China.
\end{abstract}

\section{Keywords}

Independent Directors, Female Directors, Corporate Governance

\section{Introduction}

\subsection{Research Background}

Since 1993, Tsingtao Brewery Co. employed independent directors and was listed in H Stock Market, China has opened a new chapter in independent directors.

Independent Director System was formally introduced to China through the propromulgation of guidelines for the establishment of IDS of listed companies by Securities Regulatory Committee of PRC in 2001. The board of directors of listed companies shall include at least one-third of the independent directors, who have more than five years experience of legal, economic or other related areas. Independent directors are introduced to company for improving the level of corporate governance. Robinson and Dechant [1] think a diversified board of 
directors is a good fit for the market environment and innovation.

It has a history in China that many people prefer boys over girls. With the social progress, women's status has been improved. Female directors in the board of directors are an additional source of concern. However, neither the proportion nor the number of women in Chinese listed companies is above the same companies in developed nations. In recent years, the role of women on the board has attracted much attention. Wang Mingjie and Zhu Ruyi [2] analyzed the impact of female directors on board operation and corporate performance, and concluded that female executive directors and female independent directors have a certain negative impact on corporate performance, which can be weakened by education levels of female directors.

Moreover, the accounting standards of financial listed companies are different from other general enterprises. Although a great many scholars mentioned this in their works, samples of financial listed companies were excluded because of different standards. Above all, this paper researches on China's financial listed companies under the unified accounting standard, and discusses the role of independent directors and female directors. This paper focuses on the characteristics of directors in financial listed companies in China, working as supplementary materials for corporation governance, from existing literature. In the meantime, some suggestions on further reform of corporate governance in China are put forward. However, it also has some limitations, such as the limitations of the sample, which contains only three years of data from financial listed companies.

There are four parts in the paper. The first part is an introduction, which summarizes the research background, research significance and literature review. The second part is research design and related assumptions, which states the sample of the study. There are four different hypotheses about characteristics of directors. They are relationship, professionalization, scale of independent directors and gender. The third part is the empirical analysis. The relevant data is processed in mixed section regression, panel model and 3SLS regression. The fourth part is the conclusion.

\subsection{Literature Review}

Independent directors and corporate performance were discussed in many literatures. Wei Gang [3] tested the impacts of background of independent directors on corporate performance in China and found that education background of independent directors do not have any positive effects on firm performance, while their results indicate that relationship is key to business success in China. Their results provide an important insight into the nature of effective functioning of independent directors and empirical evidence for the reform of corporate govermance in China. Wu Xiaohui and Lou Jinghui [4] found that independent directors of academic type has most wide influence, and independent directors of enterprise type has strong intention in reducing scale of supervisory board and this is meaningful to the corporate governance in the future. Comparatively, 
independent directors of government background have least influence in the corporate governance. Empirical research, Wang Yuetang, Zhao Ziye and Wei Xiaoyan [5] used OLS and 2SLS to find that proportion of independent directors to all directors is positively related to companies' financial performance, and reputation of independent directors is benefit to corporate profits.

Concerning the research on performance of female directors in corporate, Carter [6] implied that decisions concerning the appointment of women and ethnic minorities to corporate boards should be based on criteria other than future financial performance. Hu Maoli [7] indicated that a significant positive correlation between female directors and corporate value from the data of 1291 listed companies in Shanghai and Shenzhen stock market. Besides, Zhang Na [8] ender takes an empirical study of the effects of female members of the boards of directors on corporate performance based on a survey of 973 listed companies in Shanghai and Shenzhen in 2009, and that results revealed that the presence of female directors has a remarkable positive effect on corporate performance, so has the human capital. Kuang Xuewen, Peng Diyun and Lin Ni [9] suggest that Excessive hiring of female directors is not a smart move for corporate value creation.

According to the above literature, we can easily find that financial firms are always removed from the sample because of the inconsistency of accounting. Besides, few scholars are concerned about the impact of gender characteristics on corporate performance. Therefore, this paper focuses on the study of the role of female independent directors in financial listed companies separately. In that way, there is no systematic bias in measuring corporate performance if the subjects are in the same industry and comply with the same accounting standards.

\section{Design Research and Hypotheses}

Board data are manually collected from financial companies listed in A-shares from 2011-2013, totaling 45 companies. So we've got 45 companies with 3 years of data as a sample, which has 135 observable values in total. In 2011, financial companies began disclosing internal control information in their annual reports, including the information of directors. Many scholars have discussed corporate governance issues with data from 2011 to 2013 . We also choose the data of financial listed companies from 2011 to 2013 in order to make the research comparable and accessible from data. In addition, there are only 45 financial companies which listed in A-share according to the classification of Sina Finance. So we screen sample information from annual report of financial listed companies in China which posted on Sina Finance, and we get 135 observables ultimately.

The board of directors of listed companies shall include at least one-third of the independent directors, who have more than five years experience of legal, economic or other related areas in China. The regulation only clarifies the minimum and minimum requirements for independent directors. For deeper study, we focus on the influence from independent directors' background in terms of the characteristics of independent directors. 


\subsection{Hypotheses}

\subsubsection{Hypotheses about Relationship}

According to the theory of resource dependence, an organization must constantly acquire effective resources for its continuous growth and development. That is, enterprise obtains the appropriate resources to help itself develop and tide over the difficulty in times of need, which means "Guan Xi" in China. At that point we offered:

Hypothesis 1a: hypothese about government relations, independent directors with more government background will have a positive impact on the performance of companies.

Hypothesis 1b: hypothese about social relations, independent directors from other companies will have a positive impact on the performance of companies.

\subsubsection{Hypotheses about Professionalization}

Hypothesis 2a: hypothese about industry expert, more independent directors from academic research institutions, especially university professors, will have a positive impact on the performance of listed companies.

Corporate governance is closely linked to the capital chain, besides, money is commodity for a financial company, which has more to do with money. Therefore, financial talents are the first factor to consider when enterprises seek experts.

Hypothesis $2 \mathrm{~b}$ : hypothese about financial talents, more independent directors with accounting background will have a positive impact on the performance of China's financial listed companies.

With the improvement of China's market system, corporate governance is more procedural, legalized and streamlined. Professionals with a legal background are often warmly welcomed.

Hypothesis 2c: hypothese about legal experts, more independent directors with legal background will have a positive impact on the performance of China's financial listed companies.

\subsubsection{Hypotheses about Scale of Independent Directors}

Many scholars explore the relationship between the size of independent directors and corporate performance. The results are different. So we have three hypotheses.

Hypothesis 3a: the scale of independent directors is positively correlated with the performance of financial listed companies in China.

Hypothesis $3 \mathrm{~b}$ : The scale of independent directors is negatively correlated with the performance of China's financial listed companies.

Hypothesis $3 \mathrm{c}$ : There is no significant correlation between the scale of independent directors and the performance of China's financial listed companies.

\subsubsection{Hypotheses about Female Directors}

Some articles focus on the influence of directors' gender characteristics on corporate performance. Carter [6] did not find a significant relationship between 
the gender or ethnic diversity of the board, or important board committees, and financial performance for a sample of major US corporations. Their evidence also suggests that the gender and ethnic minority diversity of the board and firm financial performance appear to be endogenous. Zhang $\mathrm{Na}$ [8] drew a conclusion that the female board of directors has a positive effect on corporate performance by data from 973 listed companies. So we have two hypotheses.

Hypothesis 4a: There is a significant correlation between the proportion of female directors and the performance of financial listed companies in China.

Hypothesis $4 \mathrm{~b}$ : There is no significant correlation between the proportion of female directors and the performance of China's financial listed companies.

\subsection{Model Building and Variable Selection}

The variables used in this article are shown in the Table 1 . There are three main types of variables. The first one is a variable of corporate performance, represented by basic earnings per share. The second one is a variable of directors' background or scale. The last one is control variable.

Table 1. Variable declaration.

\begin{tabular}{|c|c|}
\hline Variable & The meaning of the variable \\
\hline eps & basic earnings per share \\
\hline gov & number of independent directors in political circles. \\
\hline academic & Number of independent directors with academic background. \\
\hline сра & The number of independent directors with accounting background. \\
\hline law & The number of independent directors with legal background. \\
\hline corp & The number of independent directors from other companies. \\
\hline fbnum & Number of female directors \\
\hline fbr & Female directors \\
\hline $\mathrm{dbr}$ & Proportion of independent directors \\
\hline fdbr & The proportion of female independent directors \\
\hline bnum & Number of directors \\
\hline supervisor & Number of supervisors \\
\hline fsvr & Number of female superviors \\
\hline assetmillion & Total assets \\
\hline first & The shareholding ratio of the largest shareholder \\
\hline first2-5 & The shareholding ratio of the 2 - 5 major shareholders. \\
\hline Dum_industry 1 & Banking virtual variables \\
\hline Dum_industry 2 & Securities industry virtual variables \\
\hline Dum_industry 3 & Insurance virtual variables \\
\hline Dum_industry 4 & Trust industry virtual variables \\
\hline Dum_industry 5 & Other dummy variables \\
\hline
\end{tabular}


Combining the previous literature and hypotheses, the model used in this article is shown below.

$$
\begin{gathered}
\text { Performance Measure }_{i}=\alpha+\text { background variables }_{i} \\
\text { Background Variables }_{\mathrm{i}}=\beta_{1} \text { gov }_{i}+\beta_{2} \text { academic }_{i}+\beta_{3} \mathrm{cpa}_{i}+\beta_{4} \mathrm{law}_{i}+\beta_{5} \text { corp }_{i} \\
\text { Quantitative Variables }_{\mathrm{i}}=\beta_{6} \mathrm{fbr}_{i}+\beta_{7} d b r_{i}+\beta_{8} d b r_{i}
\end{gathered}
$$

where Performance Measure means the company's performance variable, Background Variables means variable of the director's background, and Quantitative Variables means the number of director.

\section{Empirical Results}

Mixed cross-section estimation is applied in this paper, and the definition of performance indicators and independent variables can be seen in the above part of this article. To be more specific, the independent director's background variable contains five, the number of directors variable contains three. There are four control variables, dum_industry 2 (security industry), dum_industry 3 (insurance industry), dum_industry 4 (trust Industry) and dum_industry 5 (others). The value of a constant term actually reflects the situation of the banking industry.

The main concern is $\beta_{1}-\beta_{6}$ in the regression model, which the respect the variables, which measure the impact on corporate performance from variables, such as proportion of independent directors with background, independent directors, female directors, female independent directors.

\subsection{Mixed Cross-Section Estimation Result}

Complete regression results are given by the model from Table 2 . Independent directors with government background, legal background, and other companies' experience have a positive impact on the company's performance. The variable coefficient representing independent directors with political background is 0.497 , and it is significant at the significant level of 0.01 , which supports hypothesis 1a. In other words, independent directors with more government background will have a positive impact on the performance of companies. The variable coefficient representing independent directors with academic background is 0.481 , and it is significant at the significant level of 0.01 , which supports hypothesis $2 \mathrm{a}$. The variable coefficient representing independent directors with fiscal background is 0.564 , and it is significant at the significant level of 0.01 , which supports hypothesis $2 \mathrm{~b}$. The variable coefficient representing independent directors with legal background is 0.416 , and it is significant at the significant level of 0.01 , which supports hypothesis $2 \mathrm{c}$. Besides, the variable coefficient representing independent directors with other companies' experience background is 0.544 , and it is significant at the significant level of 0.01 , which supports hypothesis $1 \mathrm{~b}$. By contrast, neither female or the proportion of female directors associated with corporate performance is significant, which supports hypothese $4 \mathrm{a}$ and $4 \mathrm{~b}$. 
Table 2. Mixed cross-section estimation result.

\begin{tabular}{|c|c|c|}
\hline Independent variables & m_ols01 & m_ols02 \\
\hline gov & $0.497^{\star * *}(0.123)$ & \\
\hline academic & $0.481^{* * *}(0.118)$ & \\
\hline сра & $0.564^{* * *}(0.127)$ & \\
\hline law & $0.416^{* * *}(0.128)$ & \\
\hline corp & $0.544^{* * *}(0.302)$ & \\
\hline $\mathrm{fbr}$ & $-0.366(0.302)$ & \\
\hline $\mathrm{dbr}$ & $-3.945^{\star *}(1.564)$ & \\
\hline fdbr & $0.268(0.169)$ & \\
\hline bnum & $-0.136^{\star * *}(0.048)$ & $0.031^{* *}(0.012)$ \\
\hline supervisor & $-0.006(0.011)$ & $-0.006(0.012)$ \\
\hline fsvr & $-0.173(0.146)$ & $-0.026(0.164)$ \\
\hline assetmil $\sim \mathrm{n}$ & $-0.027^{\star * *}(0.008)$ & $-0.032^{* * *}(0.010)$ \\
\hline first & $-0.811^{\star * *}(0.173)$ & $-0.670^{* * *}(0.196)$ \\
\hline first 2- 5 & $-0.953^{\star * *}(0.236)$ & $-0.723^{* * *}(0.250)$ \\
\hline Dum_indu $\sim 2$ & $-0.886^{\star * \star}(0.084)$ & $-1.000^{* * \star}(0.089)$ \\
\hline Dum_indu $\sim 3$ & $-0.230^{*}(0.116)$ & $-0.199(0.123)$ \\
\hline Dum_indu $\sim 4$ & $-0.527^{\star * *}(0.171)$ & $-0.800(0.171)$ \\
\hline Dum_indu $\sim 5$ & $-0.622^{\star * \star}(0.126)$ & $-0.719^{* * \star}(0.132)$ \\
\hline _cons & $2.650^{* * *}(0.655)$ & $1.329^{\star * *}(0.205)$ \\
\hline $\mathrm{N}$ & 119 & 119 \\
\hline$r^{2}$ & 0.860 & 0.788 \\
\hline $\mathrm{r}_{-}^{2} \mathrm{a}$ & 0.835 & 0.769 \\
\hline $\mathrm{F}$ & 34.091 & 40.222 \\
\hline
\end{tabular}

Standard errors in parentheses. ${ }^{*} \mathrm{p}<0.1,{ }^{* *} \mathrm{p}<0.05^{* * *} \mathrm{p}<0.01$.

While the proportion of independent director and corporate performance is negatively correlated, which supports hypothesis $3 \mathrm{~b}$.

Regression results for control variables are given by model 2, without the influence from test variable. It is easy to find that coefficients are decrease, and the symbol for the control variable is the same as model 1 .

\subsection{Random Panel Model Analysis}

There is a serious heteroscedastic problem in mixed cross-section estimation, which may affect the regression results. Therefore, the panel data model is used to analysis the subject in order to obtain more robust and effective results. In that way, we can get more precise results for whether dependent directors or female directors affect corporate performance.

It is important to make a choice between fixed panel moder or random panel 
model. The sample of this article comes from the financial enterprises listed in China's A-share market. There is a big gap between different types of businesses. That is why industry dummy is applied here, which does not change over time. In the meantime, shareholding ration of the company is not large in the sample research interval. So the fixed effect model is not suitable for the sample. In addition, $\mathrm{P}$ value is 0.1629 in Hausman test. In a word, random effect model is applied to avoid those variables which do not vary with time (Table 3 ).

Compared with Table 2, the difference in coefficients is not very large, and the significant level is exactly the same. The variable coefficient representing independent directors with political background is 0.522 , and it is significant at the significant level of 0.01 , which supports hypothesis 1a. The variable coefficient representing independent directors with other companies' experience background is 0.544 , and it is significant at the significant level of 0.01 , which supports hypothesis $1 \mathrm{~b}$. The variable coefficient representing independent directors with academic background is 0.582 , and it is significant at the significant level of 0.01 , which supports hypothesis $2 \mathrm{a}$. The variable coefficient representing independent directors with fiscal background is 0.572 , and it is significant at the

Table 3. Random panel model estimation result.

\begin{tabular}{ccc}
\hline Independent variables & m_re01 & m_re02 \\
\hline gov & $0.522^{* * *}(0.137)$ & \\
academic & $0.500^{* * *}(0.132)$ & \\
cpa & $0.572^{* * *}(0139)$ & \\
law & $0.460^{* * *}(0.147)$ & \\
corp & $0.582^{* * *}(0.134)$ & \\
fbr & $-0.268(0.359)$ & \\
dbr & $-4.494^{* *}(1.637)$ & $0.009(0.014)$ \\
fdbr & $0.284(0.194)$ & $0.005(0.017)$ \\
bnum & $-0.166^{* * *}(0.054)$ & $-0.249(0.191)$ \\
supervisor & $0.006(0.015)$ & $-0.022^{* * *}(0.014)$ \\
fsvr & $-0.274(0.173)$ & $-0.747^{* * *}(0.289)$ \\
assetmil n & $-0.024^{* *}(0.012)$ & $-0.808^{* * *}(0.348)$ \\
first & $-0.864^{* * *}(0.246)$ & $-1.026^{* * *}(0.126)$ \\
first2-5 & $-0.965^{* * *}(0.311)$ & $-0.162(0.189)$ \\
Dum_indu 2 & $-0.954^{* * *}(0.114)$ & $-0.875^{* * *}(0.244)$ \\
Dum_indu 3 & $-0.254^{*}(0.165)$ & $-0.817^{* * *}(0.187)$ \\
Dum_indu $\sim 4$ & $-0.653^{* * *}(0.220)$ & \\
Dum_indu 5 & $-0.764^{* * *}(0.173)$ & \\
cons & $3.117^{* * *}(0724)$ & \\
$\mathrm{N}$ & 119 & \\
\hline
\end{tabular}

Standard errors in parentheses. ${ }^{*} \mathrm{p}<0.1,{ }^{* *} \mathrm{p}<0.05,{ }^{* *} \mathrm{p}<0.01$. 
significant level of 0.01 , which supports hypothesis $2 \mathrm{~b}$. The variable coefficient representing independent directors with legal background is 0.460 , and it is significant at the significant level of 0.01 , which supports hypothesis $2 c$. Neither female or the proportion of female directoers associated with corporate performance is significant, which supports hypothesis $4 \mathrm{a}$ and $4 \mathrm{~b}$. The size of directors has a negative correlation with corporate performance from the point of view of the significance of control variables. This situation may be related to the phenomenon that China's financial listed companies have insufficient experience in managing directors. The bigger the board, the less efficient it is. Moreover, the control variables of total assets and ownership concentration are also negatively correlated with corporate performance. It shows that the efficiency of corporate governance needs to be improved. Shareholders of most financial listed companies have a negative tendency to corporate performance. From the industry's virtual variables, the performance of the banking sector is significantly better than other financial sub-sectors in the sample range, such as securities, insurance and trust. This coincides with the actual situation in China. At the same time, regression results for control variables are given by model 2, without the influence from test variable.

\subsection{Endogenity and 3SLS Results}

A number of studies have shown that the composition of the board of directors will affect the performance of the business, and the performance of the board will affect the composition of the board. Hermalin [10] pointed out that the composition of the board and the company's performance are endogenous. The results ignoring endogenous problems are neither valid nor consistent if the normal least squares is the only method. In the case of the problem of endogenous, we should use 2sls (two-stage least squares procedure) or instrument variables. As for the choice of instrument variables, different documents are selected in different ways due to different research purpose. Some references do not even give specific instrument variables. Wei Gang [3] used financial leverage (DEBT) and investment opportunity (INVEST) as instrument variables. DEBT is replaced by total asset-liability ratio, INVEST is defined as the change of the total assets of the company in the year of $t$. Both of these indicators have a direct correlation with the performance of the company. The financial sector's asset-liability ratio is very different from that of other industries in China. Besides, the total assets of the financial industry are also different from those of the entity industry. In addition, the time interval of this study is narrow. It is not suitable to choose investment opportunities as instrumental variables. Combined with the research purpose of this paper and the convenience of obtaining data, we choose four different types of tobinq, ROA (return on total assets) and total asset-liability ratio as backup instrument variables to deal with endogenity.

In most of the relevant literature, scholars have adopted 3SLS (three-stage regression equation model), so do we. After the actual inspection, tobinq-a to- 
binq-b tobinq-d lev (total asset-liability ratio) and ROA (return on total assets) are used as instrument variables to deal with endogenity.

Complete regression results are given by the model from Table 4 . The independent directors with political, academic, fiscal, legal and other executives experience background have a significant impact on the performance of financial listed companies. Compared with results from panel data model and pooled panel crossed-section regression, there is no significant relationship between the proportion of independent directors and corporate performance. Neither proportion of female nor female independent directors is positive related with corporate performance.

\subsection{Robustness Test}

In addition to the proportion of independent directors, female directors and female independent directors as the test variable, we also use the virtual variables of independent directors, female directors and female independent directors to

Table 4. 3SLS regression estimate results.

\begin{tabular}{|c|c|}
\hline Independent variables & M_3sls01 \\
\hline gov & $0.912^{\star}(0.478)$ \\
\hline academic & $0.888^{\star}(0.457)$ \\
\hline cpa & $0.971^{* *}(0.482)$ \\
\hline law & $0.829^{*}(0.481)$ \\
\hline corp & $0.964^{* *}(0.468)$ \\
\hline $\mathrm{fbr}$ & $-2.395(1.745)$ \\
\hline $\mathrm{dbr}$ & $-9.514(6.454)$ \\
\hline fdbr & $-0.103(0.748)$ \\
\hline bnum & $-0.299(0.186)$ \\
\hline supervisor & $0.025(0.021)$ \\
\hline fsvr & $0.161(0.286)$ \\
\hline assetmil $\sim \mathrm{n}$ & $-0.006(0.019)$ \\
\hline first & $-0.868^{\star * *}(0.327)$ \\
\hline first $2-5$ & $-1.609^{\star * \star}(0.571)$ \\
\hline Dum_indu $\sim 2$ & $-0.862^{\star \star \star}(0.184)$ \\
\hline Dum_indu 3 & $-0.155(0.240)$ \\
\hline Dum_indu $\sim 4$ & $0.534(0.548)$ \\
\hline Dum_indu $\sim 5$ & $-0.809^{* * *}(0.256)$ \\
\hline _cons & $5.026^{\star}(2.602)$ \\
\hline $\mathrm{N}$ & 118 \\
\hline $\mathrm{R}^{2}$ & 0.575 \\
\hline Chi Square Statistic & 243.80 \\
\hline
\end{tabular}


experiment. Test result displays that the variables of independent directors' background are all significantly positive. Nevertheless, the quantitative characters of independent directors, female directors and female independent directors have not significant impact on the performance of financial listed companies. Estimated results resulting from 3SLS are robust. In other words, replacement of different types of test variables does not have a significant effect on the conclusions.

\section{Conclusion}

This paper verifies whether the characteristics of independent directors and the quantitative characteristics of independent directors, female directors, female independent directors have a significant effect on company performance. There are four major findings in the study, and they are presented as follows. Firstly, independents with government background or other company executives' background have a significant positive impact on the performance of financial listed companies in China. Secondly, independents directors with background of academe, research institution, accounting and law have a significant positive impact on the performance of financial listed companies in China. Thirdly, the gender characteristics of women in the board of directors do not have a significant impact on corporate performance. This is mainly reflected in this case that numbers characteristics of female directors and female independent directors and does not have a significant impact on the performance of financial listed companies. Finally, the ratio of independent directors to corporate performance is negatively correlated with corporate performance in mixed section regression and panel model, whereas, they have no significant correlation with corporate performance considering the problem of heteroskedastic.

\section{References}

[1] Robinson, G. and Dechant, K. (1997) Building a Business Case for Diversity. Academy of Management Executive, 11, 21-31. https://doi.org/10.5465/AME.1997.9709231661

[2] Wang, M.J. and Zhu, R.Y. (2010) Research on the Influence of Female Directors on Corporate Performance in Listed Companies. Statistics \& Decision, No. 5, 145-148.

[3] Wei, G. and Xiao, Z.Z.N. (2007) Independent Director Background and Corporate Performance. Economic Research Journal, No. 3, 92-105.

[4] Wu, X.H. and Lou, J.H. (2008) Empirical Research on the Influence of Independent Directors on Traditional Internal Governance Mechanism: Chinese Evidence Based on Multiple Regression Model and Logistic Model. Journal of Quantitative \& Technical Economics, 25, 142-152.

[5] Wang, Y.T., Zhao, Z.Y. and Wei, X.Y. (2006) Whether the Independence of the Board of Directors Affects the Performance of the Company? Economic Research Journal, No. 5, 62-73.

[6] Carter, D.A., D’Souza, F., Simkins, B.J., et al. (2010) The Gender and Ethnic Diversity of US Boards and Board Committees and Firm Financial Performance. Corporate Governance: An International Review, 18, 396-414. 
https://doi.org/10.1111/j.1467-8683.2010.00809.x

[7] Hu, M.L. (2012) Research on Female Directors in the Board of Directors and Company Value. Friends of Accounting, No. 11, 72-74.

[8] Zhang, N. (2013) Empirical Research on the Impact of Female Directors on Corporate Performance: Evidence from 973 Listed Companies in China. Collection of Women's Studies, No. 4, 38-48.

[9] Kuang, X.W., Peng, D.Y. and Lin, N. (2012) Have Female Directors Improved Corporate Financial Performance?-Empirical Evidence Based on Listed Companies in China. Jiangxi Social Sciences, 32, 218-223.

[10] Hermalin, B.E. (1998) Toward an Economic Theory of Leadership: Leading by Example. American Economic Review, 88, 1188-1206. 